\title{
Tratamento das lesões traumáticas instáveis da coluna torácica e lombar com retângulo de Hartshill*
}

\author{
Treatment of unstable thotacic spine traumatic injuries using Hartshill rectangle
}

Júllo César Pereira da Cunha' , Jorge Mauad Filho², Nelson Hely Mikael Barsam³ , José Wagner de Barros ${ }^{4}$

\section{RESUMO}

Foram avaliados 14 pacientes com lesão instável da coluna torácica e lombar, tratados com instrumentação de Hartshill. De uma forma geral, obtivemos bons resultados com a técnica proposta.

Descritores: Lesões traumáticas instáveis da coluna, lesões traumáticas da coluna torácica e lombar, retângulo de Hartshill.

\section{INTRODUÇÃO}

A redução cruenta com fixação interna é um procedimento de rotina no tratamento das lesões instáveis da coluna torácica e lombar ${ }^{(3,19)}$. Com o aparecimento de novas técnicas e materiais de síntese, houve grande avanço nas cirurgias de estabilização da coluna ${ }^{(4,5,13,15,17)}$. O retângulo(6), utilizado nas últimas décadas, tem demonstrado resultados clínicos relevantes ${ }^{(6,19)}$.

O objetivo deste estudo é avaliar 14 pacientes com lesões traumáticas instáveis da coluna torácica e lombar, tratados com instrumentação de Hartshill e com artrodese.

\section{CASUÍSTICA E MÉTODOS}

No período entre julho de 1990 e abril de 2000, 14 pacientes com lesão instável da coluna torácica e lombar foram submetidos a tratamento cirúrgico com instrumentação de Hartshill com artrodese. Dos pacientes avaliados, $11(78,6 \%)$ eram do sexo masculino etrês (21,4\%), do feminino. Aidade variou de 16 a 42 anos, com média de 29 anos, aproximadamente. Os pacientes foram submetidos a radiografias em frente e perfil (Fig. 1A-B). A coluna torácica foi acometida em seis (42,9\%) pacientes, alombar em seis (42,9\%) e a toracolombar em 2 (14,2\%).

As lesões foram classificadas conforme preconizado pela American Spinal Injury Assocíation (ASIA) ${ }^{(16)}$ (Tabela 1). Dez $(71,4 \%)$ eram do tipo C

\section{SUMMARY}

Fourteen patients with unstable thoracolumbar spine injuries treated with Hartshill's instrumentation have been evaluated. Good results were generally achieved using this technique.

Key Words: unstable spine trauma, trauma thoracolumbar spine, Hartshill's instrumentation

\section{INTRODUCTION}

Open reduction and internal fixation is routine procedure when treating unstable injuries of thoracic and lumbar spine ${ }^{(3,19)}$. New advances in fixation devices brought significant advances to spine stabilization $^{(4,5,13,15,17)}$. The rectangle ${ }^{(6)}$, used in the last decades has demonstrated relevant clinical results ${ }^{(6,19)}$.

The objective of this study is to evaluate 14 patients with unstable injury of thoracic and lumbar spine, who were treated with Hartshill's instrumentation plus arthrodesis.

\section{CASES AND METHODS}

Between July, 1990 and April, 2000, 14 patients with unstable injury of thoracic and lumbar spine underwent surgical treatment with Hartshill's instrumentation plus arthrodesis. From these patients, 11 (78.6\%) were male and three (21.4\%) female. Age ranged between 16 and 42 years, average approximately 29 years.

Patients underwent AP and lateral radiograph (Figures 1 $A-B)$. Thoracic spine was involved in six patients (42.9\%), lumbar in six (42.9\%) and thoracolumbar in 2 (14.2\%).

The injuries were evaluated according to American Spinal Injury Association (ASIA) ${ }^{(16)}$ (Table 1). Ten (71.4\%) were rated
*Trabalho realizado no Departamento de Ortopedia e Traumatologia do Hospital Escola da Faculdade de Medicina do Triângulo Mineiro - Uberaba - MG

1- Ex-Residente

2- Mestre em Ortopedia e Traumatologia pela FMRP-USP,

Responsável pelo Setor de Cirurgia da Coluna

3- Médico Ortopedista

4- Professor Titular e Responsável pela Ortopedia e Traumatologia

Endereço para correspondência: José Wagner de Barros - Disciplina de Ortopedia e Traumatologia - Departamento de Cirurgia do HE/FMTM - R. Getúlio Guaritá S/No

Bairro Abadia - CEP 38025-440 - Uberaba - MG

Trabalho recebido em 03/01/2001. Aprovado em 27/11/2001
*Work performed at Department of Orthopaedics and Traumatology from Hospital Escola da Faculdade de Medicina do Triângulo Mineiro - Uberaba - MG

1- Ex-Resident

2- Master in Orthopaedics and Traumatology from FMRP-USP,

Head of Spine Surgery Sector

3- Ortopaedist Surgeon

4- Chairman

Adress: José Wagner de Barros - Disciplina de Ortopedia e Traumatologia Departamento de Cirurgia do HE/FMTM - R. Getúlio Guaritá S/No

Bairro Abadia - CEP 38025-440 - Uberaba - MG 
e quatro $(28,6 \%)$, do tipo B. Na avaliação pré-operatória, os pacientes foram examinados clinicamente e realizada cuidadosa avaliação para averiguar danos neurológicos, conforme a escala ${ }^{(8)}$ (Tabela2). As características gerais desses pacientes avaliados encontram-se na (Tabela 3). O sistema de fixação interna utilizado constitui-se de: Retângulo de Hartshill, com 26,3mm de largura e variando de 40 a $400 \mathrm{~mm}$ de comprimento, associado a fios de Luque com diâmetros de $1 \mathrm{mme} 1,2 \mathrm{~mm}$.

Os pacientes foram submetidos à anestesia geral e posicionados em decúbito ventral. A via de abordagem foi a mediana longitudinal. Após a exposição dos processos espinhosos das vértebras acometidas inclusive duas vértebras acima e duas abaixo da lesão. Foi realizada a redução e, quando necessário, feita a laminectomia descompressiva. As lesões foram estabilizadas com retângulo de Hartshill, previamente moldado, e com os fios de Luque fixados nas lâminas acima e abaixo da lesão (Fig. 2A-B). Foi realizada artrodese com colocação de enxerto esponjoso de crista ilíaca ou do processo espinhoso.

No pós-operatório, os pacientes foram submetidos a uma nova avaliação clínica de acordo com a escala de danos neurológicos ${ }^{(8)}$ (Tabela 2) e feitos exames radiológicos aos 30, 60 e 90 dias.

Os pacientes que apresentaram condições de deambulação Frankel D e E foram liberados para marcha precoce, com uso de colete de Jewet, por 3 meses, e pacientes que não deambulavam Frankel A, B e C foram encaminhados ao serviço de Fisioterapia para reabilitação.

\section{RESULTADOS}

Dos 14 pacientes avaliados no pós-operatório, 5 (35,8\%) eram Frankel A, 7 (50\%) Frankel B, 1 (7,1\%) Frankel C e $1(7,1 \%)$ Frankel E.

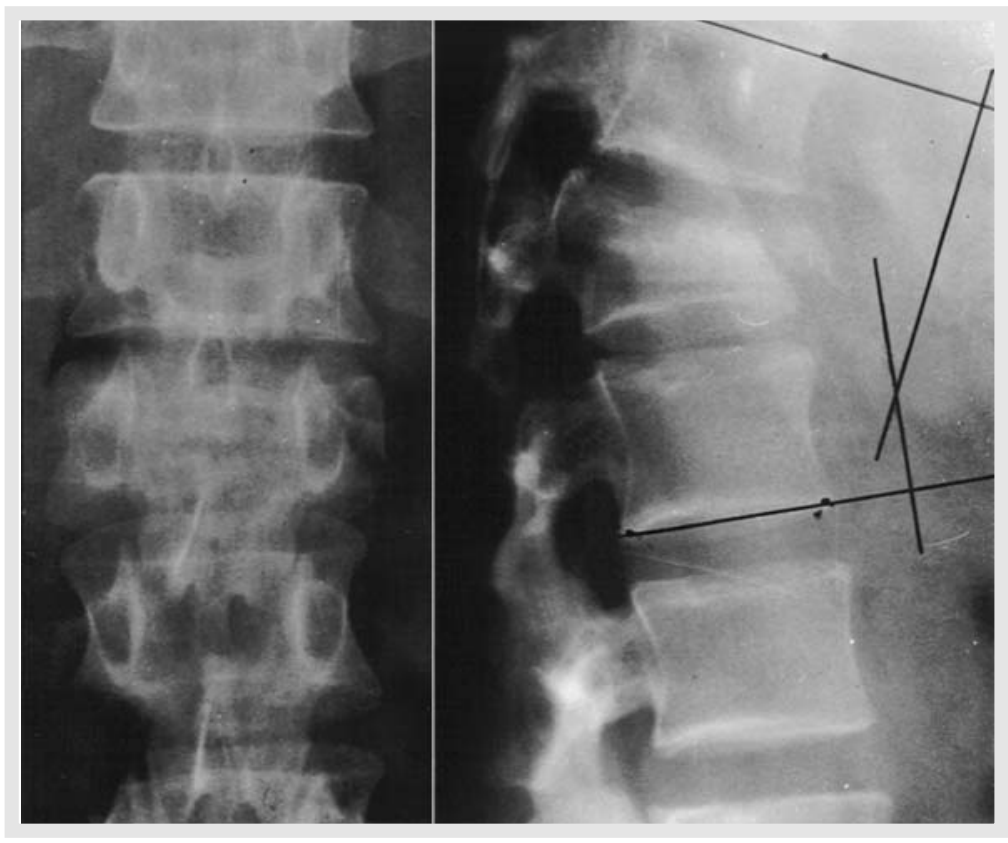

Figura 1- Fotografias de radiografias pré-operatórias da coluna lombar e torácica. A- (frente) $B$ - (perfil). Nota-se fratura em $\mathrm{LI}$, com afundamento e angulação de $280^{\circ}$.

Figure 1- Photographs of preoperative radiographs of thoracic and lumbar spine. A- (front) B- (lateral). Notice $L 1$ fracture, depressed and with $280^{\circ}$ deformity. as $C$ and four (28.6\%) as $B$. In preoperative evaluation, patients were clinically evaluated, with a careful screening for neurologic damage, according to the scale ${ }^{(8)}$ Table 2. General characteristics of these patients is in Table 3. Internal fixation device was a Hartshill's rectangle with $26.3 \mathrm{~mm}$ wide and ranging from 40 to $400 \mathrm{~mm}$ long, using Luque wires with diameters of 1 and $1.2 \mathrm{~mm}$.

Patients underwent general anesthesia, and placed in ventral decubitus. Approach as median longitudinal. After exposure of spinal processes of involved vertebras, and two vertebras above and two below the injury, a reduction was performed and when necessary, decompressive laminectomy was performed. Lesions were stabilized with the previously molded Hartshill's rectangle and Luque wires fixed to the laminas above and below the lesion (Figures 2 A-B). Arthrodesis was performed by cancellous bone graft from iliac or spinal processes.

Postoperatively patients underwent a new clinical evaluation according to the scale of neurologic damage(8) (Table 2) and radiographic evaluation performed at 30, 60 and 90 days.
1. Numero de colunas de cada vértebra acometida

A - Apenas uma coluna acometida

B - Duas colunas acometidas

C - Três colunas acometidas

II- Grau de deslizamento duas vértebras contiguas

A - Nenhum deslizamento

B - Deslizamento de até $25 \%$ entre as vértebras

C - Deslizamento maior que $25 \%$ entre as vértebras

III- Angulação resultante da lesão

A - Nenhuma angulação

B - Angulaçâo até o valor limite

C - Angulação maior que o valor limite

IV- Valores limites da angulação

A - Coluna cervical: até 11 graus de angulação

B - Coluna torácica: até 40 graus de angulação

C - Coluna lombar: até 25 graus de angulação

OBS: A classificação final é dada pela pior nota atribuida em relação aos 3 critérios avaliados.

Tabela I - Classificação da American Spinal Injury Association (ASIA) para lesões da coluna vertebra/(9).

Table I - American Spinal Injury Association (ASIA) classification of spinal injuries ${ }^{(9)}$.
Patients presenting walking conditions Frankel $D$ and $E$ were allowed early walking using a Jewet vest for 3 months, and not walking patients, Fankel A, B and C were referred to Physiotherapy for rehabilitation.

\section{RESULTS}

From the 14 evaluated patients, postoperatively 5 (35.8\%) were Frankel A, 7 (50\%) Frankel B, 1 (7.1\%) Frankel C and $1(7.1 \%)$ Frankel $E$.

From the 5 Frankel $A$ patients, 2 kept the result, 
Dos 5 pacientes Frankel A, 2 mantiveram-se, um evoluiu para $\mathrm{B}$, um para $\mathrm{O}$ e outro para E. Dos 7 Frankel B, dois evoluíram para $\mathrm{C}$, três para $\mathrm{O}$ e dois para E. O Frankel C evoluiu para E .0 Frankel E manteve-se. A evolução clínica dos pacientes, no pré e no pós-operatório, encontra-se na (Tabela 4).

Não ocorreram complicações secundárias como infecção, perda da redução ou falência de material de síntese. Apenas um paciente evoluiu com dor persistente sendo evidenciada melhora do quadro, quatro semanas após o tratamento com antiinflamatório não hormonal.

\section{DISCUSSÃO}

As lesões instáveis da coluna torácica e lombar têm sido amplamente discutidas, quanto ao tipo de tratamento operatório utilizado ${ }^{(4,5,13,15,17)}$.

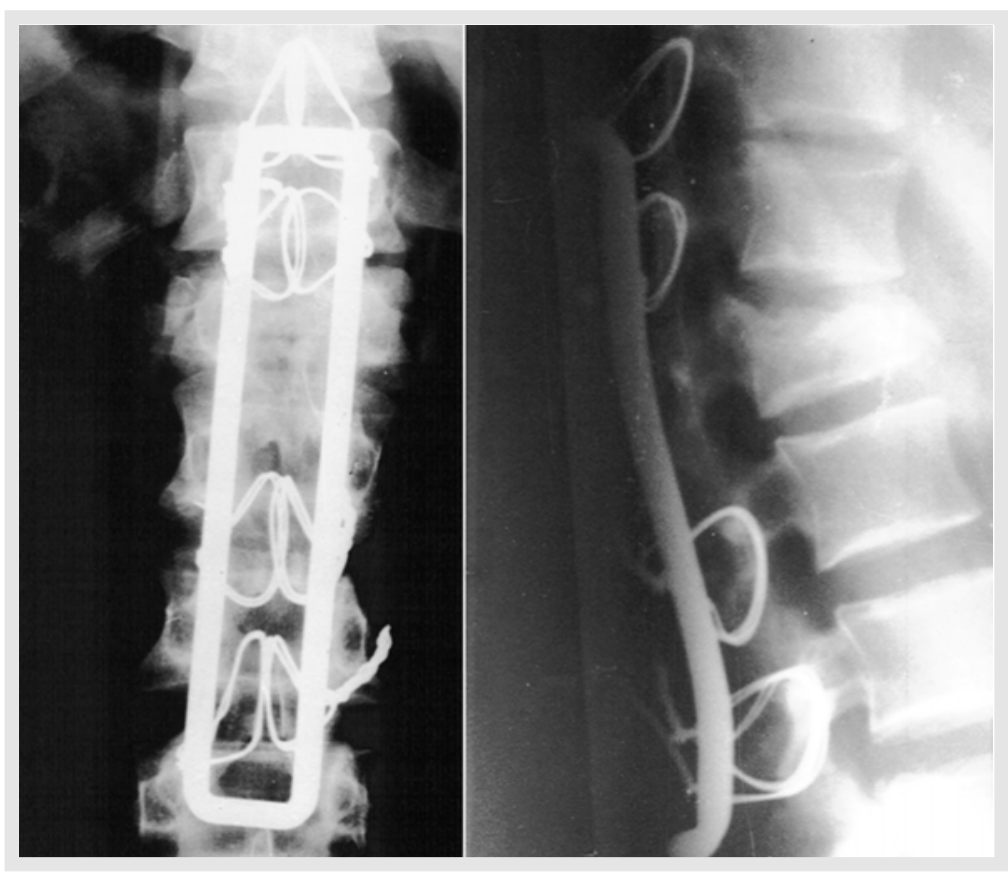

Figura 2- Fotografias de radiografias pós-operatórias da coluna lombar e torácica. A- (frente) B- (perfil). Nota-se a estabilização da fratura com o sistema de Hartshill.

Figure 2- Photograph of postoperative radiographs of lumbar and thoracic spine. A- (front) $B$ - (lateral). Notice fracture stabilization with Hartshill's rectangle. one became $B$, one $O$ and the other one became $E$. From the 7 Frankel $B$, two became $\mathrm{C}$, three $\mathrm{O}$ and two E. The Frankel $C$ patient, became E. The Frankel E remained as $E$. Postoperative clinical evolution of the patients, is in Table 4.

No secondary complication was observed, such as infection, loss of reduction or failure of the implant. Only one patient presented with persistent pain, remitting four weeks after treatment with NSAID.

\section{DISCUSSION}

Unstable injuries of thoracic and lumbar spine have been widely discussed regarding surgical treatment ${ }^{(4,5,13,15,17)}$.

Some authors recommend reconstruction and stabilization of the posterior part of the spine with the implant working as a tensor(20). Others prefer anterior approach and fixation ${ }^{(1)}$, not considering the axial load to anterior spine. And others recommend a fixation both anterior and posterior, as the best stabilizing method(10,9). Generally, all methods recommend instrumentation with arthrodesis that allow stabilizing the lesions ${ }^{(11,12,18)}$, being indicated to reduce morbidity and shorten in hospital stay ${ }^{(2,14)}$.

Reduction and fixation of fractures, with anatomical restoration of unstable injuries of thoracic and lumbar spine allow an stability that allows a better evolution in patients with a neurologic deficit(7).

The results of this series were similar to those in the literature, when compared to other instrumentation techniques ${ }^{(13,15)}$, monosegmental fixation with transpedicular screws ${ }^{(5)}$ and Harms method(4).

Os resultados obtidos foram semelhantes aos da literatura quando comparados com outras técnicas de fixação, como ins-

\begin{tabular}{cl}
\hline & \multicolumn{1}{c}{ Escala de danos neurológicos de Frankel ${ }^{(\mathbf{8})}$} \\
\hline Frankel & Características clínicas \\
\hline A & Ausência de função sensitivo-motora ao nível da lesão \\
\hline B & Ausência de função motora e sensibilidade presente \\
\hline C & Sensibilidade e motricidade presentes, mas insuficientes para marcha \\
\hline D & Sensibilidade e motricidade presentes e marcha com auxílio de órteses \\
\hline E & Função sensitivo-motora normal \\
& $\begin{array}{c}\text { Tabela 2 - Escala de danos neurológicos de Franke/(8). } \\
\text { Table 2 - Frankel's scale of neurological damage }{ }^{(8)} .\end{array}$
\end{tabular}


trumentação ${ }^{(13,15)}$, fixação monossegmentar com parafusos transpediculados ${ }^{(5)}$ e método de Har$\mathrm{ms}^{(4)}$.

O instrumental de Hartshill, por nós utilizado, proporcionou uma melhor estabilização no pós-operatório e demonstrou ser uma boa opção para a fixação posterior das lesões instáveis da coluna torácica e lombar nos pacientes avaliados.

\section{CONCLUSÕES}

A fixação interna com restauração anatômica das lesões instáveis da coluna torácica e lombar, com o retângulo de Hartshill, permitiu uma estabilidade das fraturas e demonstrou ser um método apropriado no tratamento dos pacientes com lesão traumática grave da coluna.

\begin{tabular}{c|c|c|l|c|c}
\hline Casos & Idade & Sexo & Localização & Frankel & ASIA \\
\hline 1 & 25 & $\mathrm{M}$ & Torácica & $\mathrm{E}$ & $\mathrm{C}$ \\
2 & 29 & $\mathrm{~F}$ & Torácica & $\mathrm{B}$ & $\mathrm{B}$ \\
3 & 38 & $\mathrm{M}$ & Torácica & $\mathrm{B}$ & $\mathrm{C}$ \\
4 & 20 & $\mathrm{M}$ & Lombar & $\mathrm{B}$ & $\mathrm{C}$ \\
5 & 40 & $\mathrm{~F}$ & Lombar & $\mathrm{A}$ & $\mathrm{C}$ \\
6 & 19 & $\mathrm{~F}$ & Torácica & $\mathrm{B}$ & $\mathrm{C}$ \\
7 & 42 & $\mathrm{M}$ & Lombar & $\mathrm{B}$ & $\mathrm{B}$ \\
8 & 20 & $\mathrm{M}$ & Lombar & $\mathrm{B}$ & $\mathrm{B}$ \\
9 & 21 & $\mathrm{M}$ & Torácica & $\mathrm{A}$ & $\mathrm{C}$ \\
10 & 16 & $\mathrm{M}$ & Toracolombar & $\mathrm{A}$ & $\mathrm{C}$ \\
11 & 19 & $\mathrm{M}$ & Toracolombar & $\mathrm{A}$ & $\mathrm{C}$ \\
12 & 33 & $\mathrm{M}$ & Lombar & $\mathrm{C}$ & $\mathrm{C}$ \\
13 & 20 & $\mathrm{M}$ & Torácica & $\mathrm{A}$ & $\mathrm{C}$ \\
14 & 25 & $\mathrm{M}$ & Lombar & $\mathrm{B}$ & $\mathrm{D}$ \\
\hline
\end{tabular}

Tabela 3 - Características gerais dos pacientes submetidos ao tratamento operatório quanto à idade, sexo, localização, danos neurológicos e tipo de lesão.

Table 3 - General aspects of patients who underwent surgery regarding age, sex, location, neurological data and kind of injury.

\begin{tabular}{c|c|c}
\hline Casos & Pré-operatório & Pós-operatório \\
\hline 1 & $\mathrm{E}$ & $\mathrm{E}$ \\
\hline 2 & $\mathrm{~B}$ & $\mathrm{E}$ \\
\hline 3 & $\mathrm{~B}$ & $\mathrm{C}$ \\
\hline 4 & $\mathrm{~B}$ & $\mathrm{C}$ \\
\hline 5 & $\mathrm{~A}$ & $\mathrm{D}$ \\
\hline 6 & $\mathrm{~B}$ & $\mathrm{D}$ \\
\hline 7 & $\mathrm{~B}$ & $\mathrm{E}$ \\
\hline 8 & $\mathrm{~B}$ & $\mathrm{D}$ \\
\hline 9 & $\mathrm{~A}$ & $\mathrm{~B}$ \\
\hline 10 & $\mathrm{~A}$ & $\mathrm{~A}$ \\
\hline 11 & $\mathrm{~A}$ & $\mathrm{E}$ \\
\hline 12 & $\mathrm{C}$ & $\mathrm{E}$ \\
\hline 13 & $\mathrm{~A}$ & $\mathrm{~A}$ \\
\hline 14 & $\mathrm{~B}$ & $\mathrm{D}$ \\
\hline
\end{tabular}

The Hartshill's rectangle used by us, allowed a best postoperative stabilization and demonstrated to be a good option for posterior fixation of unstable injuries of thoracic and lumbar spine in this group of patients.

\section{CONCLUSIONS}

Internal fixation and anatomical restoration of unstable lesions of thoracic and lumbar spine with Hartshill's rectangle allowed stability to the fractures and proved to be adequate in treatment of patients with severe traumatic spinal injury.

Tabela 4 - Evolução clínica dos pacientes no pré e pós-operatório segundo a escala de danos neurológicos de Frankel.

Table 4 - Pre and post operative evolution of the patients according to Frankel's rating.

\section{REFERÊNCIAS BIBLIOGRÁFICAS}

1. Aebi, M.: Operative Behandlung von Wirbels frakturen - dorsale oder ventrale instrumentation. Op Journal 12: 182-187, 1996.

2. Bedbrook,G.M.: Use and disure of surgery in limbo-dorsal fractures. J Western Pacific Orthop Assn 6: 5-26, 1969.

3. Brum, P. R., Labronici, P. J., D'Angelo,D. S. \&Amaral, C. A B.: Tratamento cirúrgico das fraturas instáveis da coluna toracolombar. RevBras Ortop 30: 125-130,1995.

4. Defino, H. L. A., Fuentes, A. E. R. \& Rejaili, W. A: Tratamento das fraturas da colina toracolombar pelo método de Harms. Rev Bras Ortop 32: 546-554, 1997

5. Defino, H. L. A., Fuentes, A. E. R., Remond, P. H. \&Valim, E.: Fixação monossegmentar das fraturas da coluna toracolombar. Rev Bras Ortop 33: 119-124, 1998

6. Dove, J: Internal fixation of the lumbar spine. The Hartshill rectangle. Clin Orthop 203: 135-140, 1986.

7. Flesch, J.R., Leíder, L.L.,Erikson, D.L., Chou, S.N. \& Bradford, D.S. Harrington instrumentation and spine fusion for unstable fractures and fractures-dislocations of thoracic and lumbar spine. J Bane Joint Surg [Am] 59: 143-153, 1977.

8. Frankel, H. L. Hancock, O. 0. \& Hyslop, G.: The spine wíth paraplegia and tetraplegia. Paraplegia 7: 225, 1969.

9. Harms, J.: Screw-threaded rod system ín spinal fusion surgery. State of the art review. Spine 6: $541-577,1992$.

10. Harms, J. \& Stoltze,D.: Ihe indications and principles of correction of pot-traumatic deformitíes. Eur Spine J 1:142-151, 1992.

11. Harrington, P. R.: Treatment of scoliosis. Correction and internal fixation by spine instrumentation. J Bane Joint Surg [Am] 44: 591,1962.

12. Harrington, P.R: Instrumentation in spine instability other than scoliosis. S Afr Surg 5: 7-12,1967.

13. Harrington, P.R. \& Dickson, J.H.: The development and further prostects of internal fixatíon of the spine. Isr J Med Sci 9: 773-778, 1973.

14. Katznelson, A.M.: Stabilization of the spine in traumatic paraplegia. Paraplegia 7: 33-37, 1969.

15. Luque, E., Cassis, H. \& Ramirez-Wiella, G.: Segmental spinal instrumentation in the treatment of fractures of the thoracolumbar spíne. Spine 7: 312, 1982.

16. Meyer, P.: New Spine Fracture Clasification System, Annual meeting of the AAPM\&R, Chicago, 1996.

17. Munford, J.,Weinsten, N., Spratt, K. F. Et al.: Thoracolumbar burst fractures: The clinical efficacy and outcome of monoperative managemente. Spine 8: 955-970, 1993.

18. Oliveira, R.P., Barros Filho, T.E.P., Greve, J.M.D'A., Rodrigues, N.R. \& Basíle Jr., R.: Fraturas vertebraís do sebmento toracolombar: descompressão cirúrgica. Rev Bras Ortop 27: 699-704, 1992.

19. Puertas, E. B., Chagas, J. O. M. \& Kasinski, S. K.: Trauma toracolombar. Rev Bras Ortop 27:138-140, 1992.

20. Staufer, E.S.: "The use of the AO 'fixateur interne' for thoracic and lumbarfractures", in Brídwell, K. H. \& Oewald, R. L. (eds).: The text-book of spinal sugery, Phíladelphia, J.B Lippincott, 1997. p. 1949-1955. 